\title{
De collateral damage van een wereldwijde crisis: de impact van de COVID-19-pandemie op de werkbeleving van Maag-Darm-Lever-artsen
}

\author{
Evelien H. van Leeuwen \\ UMC Utrecht, Kwaliteit van Zorg en Patiëntveiligheid, en Universiteit \\ Utrecht, Bestuurs- en Organisatiewetenschappen \\ e.h.vanleeuwen@uu.nl
}

Toon W. Taris

Universiteit Utrecht, Arbeids- en Organisatiepsychologie

t.taris@uu.nl

\begin{abstract}
Samenvatting
In deze studie onderzochten we de impact van COVID-19 gerelateerde veranderingen in het werk van Maag-Darm-Lever-artsen (MDL-artsen) op hun werkbeleving. Specifiek bestudeerden we hoe het werk van MDL-artsen is veranderd als gevolg van de COVID-19-crisis, en wat voor effect dit heeft op burn-outklachten, bevlogenheid, werktevredenheid, inzetbaarheid, werkvermogen, lichamelijke en psychische gezondheid. $248 \mathrm{MDL}$-artsen uit Nederlandse ziekenhuizen vulden in oktober 2020 een vragenlijst in, tijdens de aanloop naar de tweede COVID-19-golf. Uit de resultaten blijkt dat de COVID-19-crisis voor een statistisch significante afname in het aantal werkuren zorgde, en een klein deel van de MDL-artsen werkte tijdelijk op een andere afdeling om te zorgen voor COVID-19-patiënten. De impact van deze veranderingen op de werkbeleving van MDL-artsen blijkt ten tijde van dit onderzoek gering. Hoewel MDL-artsen vóór de COVID-19-crisis iets positiever waren over hun werkvermogen en lichamelijke en psychische gezondheid, hebben de veranderingen in hun werk als gevolg van de COVID19-crisis geen duidelijke negatieve effecten op andere aspecten van hun werkbeleving. Dit onderzoek benadrukt het belang om zorgmedewerkers niet over één kam te scheren in het trekken van conclusies over de impact van de COVID-19-crisis. Verschillende groepen kunnen de COVID-19-crisis anders beleven, en ook binnen beroepsgroepen kan variatie bestaan.
\end{abstract}


Aandacht voor werkbeleving blijft belangrijk omdat artsen die meer belasting/werkdruk ervaren, minder gunstige uitkomsten rapporteerden.

\begin{abstract}
The collateral damage of a worldwide crisis: The impact of the COVID-19 pandemic on the work experiences of gastroenterologists

This study investigated the impact of work changes as a result of COVID-19 on the work experiences of 248 gastroenterologists (GEs) working in Dutch hospitals. Specifically, we studied how the work of GEs changed as a result of the COVID-19 crisis, and what effect this has on burnout, engagement, job satisfaction, employability, work ability, physical and psychological health. Participants completed a questionnaire in the run-up to the second COVID-19 wave in October 2020. Results show that the COVID-19 crisis significantly reduced their number of working hours, and a small proportion of GEs worked temporarily in other units to care for COVID-19 patients. At the time of this study, the impact of these changes on the work experiences of GEs appears to be small. Although before the COVID-19 crisis GEs were slightly more positive about their work ability, physical and mental health than during this crisis, the changes in their work as a result of the COVID-19 crisis had no apparent negative effects on other aspects of their work experience. This study underscores the importance of not equating healthcare workers in drawing conclusions about the impact of the COVID-19 crisis. Different groups can experience the COVID-19 crisis differently, and variation can also exist within professional groups. Attention for work perceptions remains important because doctors who experienced more stress/work pressure reported less favorable outcomes.
\end{abstract}

Keywords: work experience, physicians, COVID-19, crisis, burn-out, employability

Een crisis is een situatie die volgens de publieke opinie een bedreiging vormt voor de kernwaarden van de maatschappij en/of duurzame systemen in de maatschappij, die dringend moet worden aangepakt in tijden van grote onzekerheid (Boin et al., 2020; Rosenthal et al., 2001). Een snelle ("fast burning") crisis verwijst naar een specifieke gebeurtenis en kent vaak een duidelijk begin en einde, bijvoorbeeld een aardbeving. Een langzame ("slow 
burning") dan wel sluipende ("creeping") crisis (Boin et al., 2020) heeft daarentegen betrekking op een langer durende crisis die geen duidelijk begin- en eindpunt kent, en die bestaat uit verschillende fasen waarin de situatie nu eens in ernst toeneemt en dan weer afzwakt.

De internationale COVID-19-pandemie is een sluipende crisis. Na eind 2019 te zijn opgedoken in Wuhan, China, sloeg het virus begin 2020 ook in Nederland hard toe. De aantallen COVID-19-patiënten in de Nederlandse ziekenhuizen groeiden snel, zodanig dat de reguliere zorg sterk moest worden afgeschaald en personeel moest worden vrijgemaakt voor de strijd tegen het virus. Een handvol krantenkoppen uit die periode: "Tweede golf: Druk op personeel neemt weer toe", "Helft artsen bang om coronavirus mee naar huis te nemen" en "Zorgverlener houdt huidige situatie niet vol". Veel zorgverleners, in Nederland en elders, gaven in de media aan fysiek en emotioneel uitgeput te zijn, en een deel voelde zich onveilig en onvoldoende beschermd tegen het virus (Spoorthy et al., 2020). Eerdere studies naar pandemieën van infectieziekten, zoals SARS, de Mexicaanse griep $\left(\mathrm{H}_{1} \mathrm{~N}_{1}\right)$ en de vogelgriep $\left(\mathrm{H}_{5} \mathrm{N1}\right)$, lieten zien dat zorgmedewerkers die zorg dragen voor patiënten met het betreffende virus tijdens deze crises meer kans hadden op psychosociale problematiek als stress, depressie, burn-out, angst en PTSS (Stuijfzand et al., 2020) en verminderde inzetbaarheid (Ives et al., 2009); hetzelfde lijkt te gelden voor het werken met COVID-19-patiënten (Lai et al., 2020). De lange periode waarin deze sluipende crisis Nederland in een houdgreep heeft, zorgt ervoor dat zorgmedewerkers gedurende een lange tijd in een steeds veranderende en daarmee zeer onzekere situatie moeten werken. Dat maakt het extra belangrijk om de impact van deze crisis op de werkbeleving van zorgmedewerkers te onderzoeken.

Dat medisch personeel dat direct betrokken was bij de zorg voor COVID19-patiënten, werd blootgesteld aan een zeer hoge werkdruk, is wel duidelijk (zie bijv. Lai et al., 2020; Ripp et al., 2020), maar onduidelijk is hoe dit ligt voor medisch personeel dat qua specialisatie niet direct betrokken was bij de zorg voor deze specifieke groep patiënten. Deze groep wordt vaak niet meegenomen in onderzoek naar de impact van de COVID-19-pandemie op hun werkbeleving. Toch is het belangrijk om inzicht te krijgen in hoe deze groep het werk tijdens deze crisis ervaarde, omdat ook hun werk op meerdere vlakken is veranderd. Werkroutines moesten worden aangepast, medewerkers werden elders ingezet of moesten vanuit huis werken, geplande ingrepen konden geen doorgang vinden, en een deel van hun collega's was wél direct betrokken bij de zorg voor COVID-19-patiënten en stond onder zware druk. Onduidelijk is hoe deze vorm van collateral damage de werkbeleving van deze groep beïnvloedt. 
In deze studie gaan we specifiek in op de werkbeleving van Maag-DarmLever-artsen (MDL-artsen) ten tijde van de COVID-19-crisis. Het gros van deze groep medisch specialisten was niet direct betrokken bij de zorg voor COVID-19-patiënten, maar het is om bovengenoemde redenen goed denkbaar dat de crisis ook effect had op hun werkbeleving. In dit artikel onderzoeken we of met COVID-19 samenhangende veranderingen in het werk de werkbeleving van deze groep artsen beïnvloedden. Uitgangspunt daarbij is dat de COVID-19-crisis effect kan hebben gehad op de kenmerken van het werk van MDL-artsen. Dit kan bijvoorbeeld van invloed zijn op de autonomie in hun werk, hun werkdruk, lichamelijke en emotionele belasting. Deze kenmerken kunnen vervolgens effect hebben op werkuitkomsten zoals de bevlogenheid, burn-outklachten, tevredenheid, werkvermogen, inzetbaarheid en gezondheid van deze artsen.

\subsection{COVID-19 en werkbeleving}

Het theoretische kader van deze studie is vooral gebaseerd op het Job Demands-Resources (JD-R) model (Demerouti et al., 2001; Schaufeli \& Taris, 2014). De kern van dit model is het onderscheid tussen taakeisen ("demands", dat wil zeggen de fysieke, sociale en organisatorische kenmerken van het werk die fysieke of mentale inspanning vereisen en daarom samenhangen met bepaalde fysiologische en psychologische kosten), en hulpbronnen ("resources", gedefinieerd als de fysieke, sociale of organisatorische aspecten van het werk die functioneel zijn in het bereiken van de werkgerelateerde doelen, taakeisen en de daarmee samenhangende fysiologische en psychologische kosten reduceren, en/of persoonlijke groei en ontwikkelingen stimuleren). In deze studie keken we naar vier werkkenmerken: drie taakeisen (kwantitatieve werkdruk, emotionele belasting en fysieke belasting) en één hulpbron (autonomie). Deze werkkenmerken zijn gekozen op basis van inzichten uit de literatuur over de centrale werkkenmerken in de werksituatie, en vanwege hun relevantie in de werksituatie van MDL-artsen. Onderzoek naar bekende modellen over werkkenmerken zoals het Job Demands-Resources model en het Job Demands-Control model laat zien dat (kwantitatieve) werkdruk en autonomie in veel beroepen centrale kenmerken van de werksituatie zijn (bijv. De Lange et al., 2003; Fila, 2016; Schaufeli \& Taris, 2014), zodat het van belang leek om deze concepten in ieder geval mee te nemen. Daarnaast zijn deze werkkenmerken gekozen vanwege hun relevantie in de werksituatie van MDL-artsen, waarbij deze groep professionals bekendstaat om hun hoge mate van autonomie (Noordegraaf, 2015) en een hoge werkbelasting (bijv. Shanafelt et al., 2015). Tot slot zijn deze werkkenmerken relevant om in deze studie mee te nemen vanwege de waarschijnlijkheid dat de COVID-19-crisis 
effect kan hebben gehad op deze specifieke werkkenmerken. De COVID19-crisis kan er bijvoorbeeld voor hebben gezorgd dat de emotionele belasting van MDL-artsen toenam, doordat zij zich zorgen maakten om patiënten van wie geplande behandelingen en operaties noodgedwongen moesten worden uitgesteld. Ten slotte, fysieke belasting is meegenomen omdat veranderingen in werkdruk of locatie van het werk ook fysieke impact zouden kunnen hebben.

Het model veronderstelt dat hoge taakeisen (zoals werkdruk en emotioneel veeleisend werk) vooral gevolgen zullen hebben voor de gezondheid (bijvoorbeeld een hoge mate stress en strain, vaak gemeten in termen van burn-outklachten). De aanwezigheid van voldoende hulpbronnen (zoals autonomie) zal daarentegen vooral motivationele gevolgen hebben, denk aan een hoge mate van bevlogenheid. Deze gevolgen hebben vervolgens effect op het functioneren van werkenden, waaronder bijvoorbeeld werkprestatie. Alhoewel het model de afgelopen jaren op diverse manieren is verfijnd (bijvoorbeeld door onderscheid te maken tussen uitdagende en hinderende taakeisen, Crawford et al., 2010, en door persoonlijke kenmerken in het model onder te brengen, zie Schaufeli \& Taris, 2013), zijn deze basale veronderstellingen de afgelopen twee decennia in een groot aantal studies in een brede verscheidenheid aan beroepen bevestigd (Lesener et al., 2019; Schaufeli \& Taris, 2014; Taris et al., 2017, voor reviews). Het model vormt daarmee een goede basis voor onze studie naar de effecten van mogelijk veranderende kenmerken van het werk van MDL-artsen als gevolg van de COVID-19-crisis op de werkuitkomsten van deze groep.

COVID-19, werkkenmerken en werkbeleving. Toen de aantallen COVID19-patiënten in Nederland in maart-april 2019 snel groeiden, troffen ziekenhuizen allerlei maatregelen om deze toename het hoofd te kunnen bieden. Die maatregelen waren niet in alle ziekenhuizen hetzelfde, bijvoorbeeld als gevolg van regionale verschillen in het aantal besmettingen; de nood was niet overal even hoog. Soms werd de zorgcapaciteit vergroot door electieve (nieturgente) zorg uit te stellen en cliënten sneller naar huis te sturen (Wallinga et al., 2020). Het aantal beschikbare zorgprofessionals kon worden vergroot door verlof in te trekken, medewerkers op zwaar belaste afdelingen in te zetten, hen te laten werken in tijdelijke, wisselende teams, of door hen meer dan het contractueel vastgelegde aantal werkuren te laten draaien (bijv. Brubaker, 2020; Stalpers et al., 2021). Soms ook konden zorgprofessionals een beroep doen op mentale ondersteuning als de met de pandemie samenhangende stress te groot dreigde te worden, om zo uitval te voorkomen (De Vroege et al., 2020; Stuijfzand et al., 2020). Hygiënemaatregelen werden geïntensiveerd om besmettingen onder het personeel te voorkomen (Starremans, 
2020). Afdelingen waarop COVID-19-patiënten werden verpleegd, werden gewoonlijk strikt gescheiden van andere afdelingen, en communicatie werd vaak vooral online verzorgd (vgl. Gan et al., 2020).

Deze en andere maatregelen hadden een grote impact op de manier waarop de zorg in de Nederlandse ziekenhuizen werd georganiseerd, en het lijkt aannemelijk dat deze veranderingen niet alleen zorgprofessionals hebben geraakt die werkzaam waren op afdelingen waar COVID-19-patiënten verbleven, maar ook het werk van andere zorgprofessionals hebben beïnvloed. Deze veranderingen kunnen ook effect hebben gehad op werkkenmerken van in ziekenhuizen werkzame MDL-artsen. Wat die effecten precies zijn geweest, is moeilijk te zeggen. Dat hangt immers af van de maatregelen die een ziekenhuis heeft getroffen voor bepaalde afdelingen en bepaalde functiegroepen. In die zin is het lastig, zo niet onmogelijk, om algemene verwachtingen te formuleren over de effecten van COVID-19 gerelateerde veranderingen in het werk op de werkkenmerken en werkuitkomsten van MDL-artsen.

Wel veronderstellen we dat eventuele veranderingen altijd een zekere mate van aanpassing van de kant van artsen zullen vragen en daarmee op zichzelf al belastend zullen zijn. Het gaat feitelijk immers om een al dan niet beperkte, gedwongen reorganisatie van de werkzaamheden en (delen van) de organisatie, en dergelijke onverwachte en onprettige veranderingen hebben vaak negatieve gevolgen voor individuele werkuitkomsten als welzijn, betrokkenheid en tevredenheid (zie bijv. Burke \& Greenglass, 2001; Probst, 2003; Ruhle et al., 2020; Stalpers et al., 2021; Taris, 2002). In de terminologie van het JD-R model: dergelijke veranderingen zullen ervoor zorgen dat artsen een zekere mate van fysieke en/of mentale inspanning zullen moeten leveren, wat theoretisch in ieder geval op kortere termijn zou moeten leiden tot minder gunstige werkuitkomsten (Demerouti et al., 2001). Hoewel de COVID-19 gerelateerde maatregelen vanwege hun transiënte karakter niet als structurele kenmerken van het werk van MDL-artsen beschouwd kunnen worden, zal de invoering van deze maatregelen dus dezelfde effecten hebben als taakeisen.

Daarnaast kan worden verondersteld dat dergelijke maatregelen er ook voor zullen zorgen dat andere werkkenmerken veranderen. Het werken op een andere locatie dan gebruikelijk of het herplaatsen van personeel kan bijvoorbeeld betekenen dat noodzakelijke faciliteiten afwezig of minder goed toegankelijk zijn, zodat een goede taakvervulling moeilijker wordt. De geringere beschikbaarheid van plekken op de Intensive Careafdelingen van ziekenhuizen zal betekenen dat sommige patiënten niet tijdig de zorg kunnen ontvangen die zij (in ieder geval naar het oordeel van de betreffende patiënt en diens familie) dringend nodig hebben, wat voor een hogere emotionele belasting van artsen kan zorgen. Het moeten 
werken volgens strikte protocollen om besmetting te voorkomen kan het gevoel van autonomie aantasten. Hier zijn artsen doorgaans allergisch voor gezien hun professionele karakter, waar autonomie hoog in het vaandel staat (bijv. Noordegraaf, 2020). Daarnaast kan het ervoor zorgen dat er minder tijd overblijft voor andere taken, zodat artsen een hogere werkdruk ervaren (Taris, in druk). Als deze veranderingen ervoor zorgen dat artsen meer verantwoordelijkheid gaan dragen, zal dit eveneens leiden tot een hogere belasting. Anders gezegd, enerzijds zal de aanpassing aan nieuwe werkomstandigheden inspanning vereisen die ervoor zorgt dat er minder energie overblijft voor andere zaken (en daarmee de feitelijke en/of ervaren werkbelasting verhoogt), anderzijds zullen maatregelen ook de ervaren hulpbronnen - in ieder geval de ervaren autonomie - aantasten.

\subsection{De huidige studie}

Figuur 1 presenteert het in deze studie gehanteerde theoretische model. De effecten van taakeisen en hulpbronnen op de werkuitkomsten van werknemers zijn inmiddels goed gedocumenteerd in onderzoek op basis van modellen als het JD-R model (Demerouti et al., 2001) en Karasek en Theorell's Demand-Control(-Support) model (1990; Fila, 2016). Op basis van deze modellen verwachten we dat naarmate deelnemers meer taakeisen ervaren (kwantitatieve werkdruk, emotionele belasting en fysieke belasting), ze minder gunstige werkuitkomsten zullen rapporteren (Hypothese 1a). Voor de hulpbron autonomie geldt het omgekeerde: naarmate deelnemers meer autonomie ervaren, zullen zij gunstigere werkuitkomsten rapporteren (Hypothese ib).

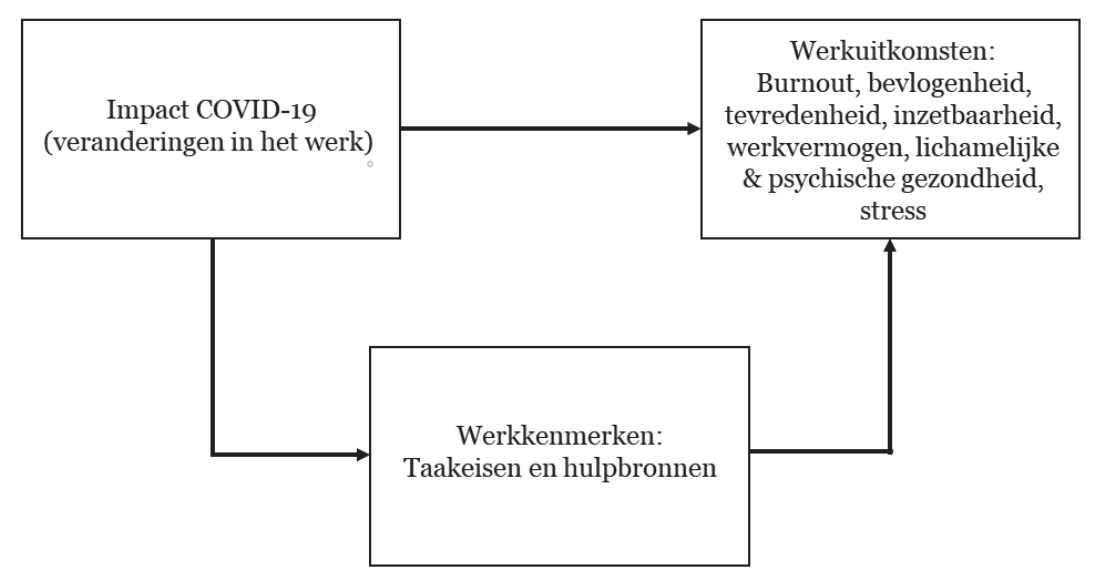

Figuur 1 Theoretisch model 
In deze studie keken we naar vier mogelijke veranderingen in het werk van MDL-artsen als gevolg van COVID-19 gerelateerde maatregelen: verandering in (1) het aantal gewerkte uren, (2) de locatie waar MDL-artsen hun werk uitvoerden, (3) de mate van verantwoordelijkheid die zij droegen, en (4) de moeilijkheidsgraad van hun werk. Deze veranderingen werden gekozen op basis van gesprekken met de bij dit onderzoek betrokken klankbordgroep, bestaande uit drie MDL-artsen die werkzaam waren in verschillende ziekenhuizen. Dergelijke veranderingen zullen in principe aanpassing van de kant van de arts vereisen en een zekere mate van inspanning vragen, zodat verwacht wordt dat ze gepaard zullen gaan met negatieve gevolgen voor de werkuitkomsten van MDL-artsen (gemeten in termen van burn-outklachten, bevlogenheid, werk- en loopbaantevredenheid, duurzame inzetbaarheid, werkvermogen, en lichamelijke en psychische gezondheid). We veronderstellen daarom dat naarmate MDL-artsen meer te maken hebben met dergelijke veranderingen (COVID-19 gerelateerde veranderingen), zij minder gunstige werkuitkomsten zullen rapporteren (Hypothese 2).

Daarnaast veronderstellen we dat naarmate MDL-artsen meer veranderingen in hun werk ervaren als gevolg van COVID-19, zij minder hulpbronnen ervaren, namelijk minder autonomie in hun werk ervaren, en hogere scores geven aan hun taakeisen, namelijk meer werkdruk, fysieke en emotionele belasting (Hypothese 3). In samenhang leiden Hypothesen 2 en 3 tot de verwachting dat de relatie tussen COVID-19 gerelateerde veranderingen en werkuitkomsten (burn-outklachten, bevlogenheid, werk- en loopbaantevredenheid, duurzame inzetbaarheid, werkvermogen, en lichamelijke en psychische gezondheid) ten minste deels gemedieerd wordt door werkkenmerken (taakeisen en hulpbronnen) (Hypothese 4).

Naast deze hypothesen wordt in deze studie ook gekeken naar mogelijke andere gevolgen van COVID-19 voor de werkbeleving van MDL-artsen, met name of er een verandering had plaatsgevonden in enkele specifieke werkuitkomsten (werkvermogen, en lichamelijke en fysieke gezondheid). Op deze manier hoopten we een breder inzicht te krijgen in de consequenties van de COVID-19-crisis voor MDL-artsen. Voor deze toegevoegde aspecten werden geen hypothesen geformuleerd; de vraag naar de consequenties van het COVID-19-virus voor deze aspecten heeft vooral een exploratief karakter. 


\section{Methode}

\subsection{Participanten}

Om de hierboven geformuleerde hypothesen en onderzoeksvraag te toetsen dan wel te beantwoorden werd een cross-sectioneel vragenlijstonderzoek uitgevoerd onder alle in Nederland werkzame MDL-artsen. Het onderzoek werd medio oktober 2020 uitgevoerd tijdens de aanloop naar de tweede COVID-19-golf in Nederland. Aan MDL-artsen werd via hun beroepsvereniging per e-mail gevraagd om deel te nemen aan dit onderzoek. Formele ethische goedkeuring was niet nodig aangezien eerder was vastgesteld dat dit type onderzoek buiten de reikwijdte van de Wet medisch-wetenschappelijk onderzoek met mensen (WMO) valt. De online vragenlijst startte met een uitleg over de inhoud en het doel van de studie. Medewerkers werd verzekerd dat deelname anoniem was en op vrijwillige basis gebeurde en dat er vertrouwelijk met de gegevens zou worden omgegaan. Vervolgens werd de deelnemers gevraagd om informed consent, in lijn met de Algemene Verordening Gegevensbescherming.

De uiteindelijke respons bedroeg $29 \%(N=248$, waarvan 192 medisch specialisten en 56 arts-assistenten). De MDL-artsen in deze studie waren gemiddeld 44.64 jaar oud $(S D=10.93)$, werkten gemiddeld 47.95 uur per week vóór de COVID-19-crisis $(S D=11.45)$ en 39.84 uren per week tijdens het hoogtepunt van de COVID-19-crisis $(S D=13.60) .52 \%$ was man, het merendeel woonde samen met een partner (92\%) en $58 \%$ had thuiswonende kinderen. $45 \%$ werkte in loondienst en $55 \%$ was vrijgevestigd. De meeste artsen werkten in Noord-Holland (24\%), Zuid-Holland (22\%) en Gelderland (13\%). Hoewel onduidelijk is of de steekproef representatief was voor alle MDL-artsen werkzaam in Nederland, is er geen duidelijke reden om te vermoeden dat de steekproef afwijkt van de Nederlandse populatie van MDL-artsen.

\subsection{Variabelen}

Aan de artsen is gevraagd hoeveel veranderingen er optraden in hun werksituatie als gevolg van COVID-19. Lichamelijke belasting, autonomie, emotionele belasting en kwantitatieve werkdruk werden gemeten als voor deze beroepsgroep belangrijke werkkenmerken. Ten slotte werden werkuitkomsten gemeten in termen van burn-outklachten, bevlogenheid, werk- en loopbaantevredenheid, duurzame inzetbaarheid, werkvermogen, en lichamelijke en psychische gezondheid. De vragenlijst werd voorgelegd aan een klankbordgroep, bestaande uit drie leden - werkzaam als MDL-arts - van het bestuur van de Nederlandse Vereniging voor Maag-Darm-Leverartsen. 
Op basis van de suggesties van de klankbordgroep werd de vragenlijst op enkele punten aangepast (bijvoorbeeld met betrekking tot de veranderingen in het werk als gevolg van COVID-19) en aan de participanten voorgelegd.

COVID-19 gerelateerde veranderingen. We vroegen de deelnemers in hoeverre hun werk was veranderd door de COVID-19-crisis (in termen van werkuren, de locatie waar zij hun werk uitvoerden, de mate van verantwoordelijkheid die zij hadden in hun werk, en de moeilijkheidsgraad van hun werk). Voor werkuren is gevraagd naar het aantal werkuren dat per week werd gemaakt voor de COVID-19-crisis en tijdens het hoogtepunt van de COVID-19-crisis. Voor de locatie waar zij werkten, is gevraagd om aan te geven waar ze voor de COVID-19-crisis werkten (op de eigen afdeling, thuis of overig) en waar ze tijdens het hoogtepunt van de COVID-19-crisis werkten (op de eigen afdeling, thuis, corona-cohortafdeling, op de Intensive Care-afdeling, ik werkte in deze periode niet of overig). Voor de mate van verantwoordelijkheid en de moeilijkheidsgraad in hun werk is gevraagd of deze toe- of afgenomen was in de periode van voor de COVID-19-crisis ten opzichte van de situatie tijdens het hoogtepunt van de COVID-19-crisis, en of deze ten tijde van het invullen van de vragenlijst was teruggekeerd naar het niveau van voor de COVID-19-crisis.

De indexvariabele 'COVID-19 gerelateerde veranderingen' geeft weer hoeveel veranderingen de deelnemers in hun werk hadden ervaren. De categorie "geen veranderingen" geeft aan dat de participanten op geen van de genoemde aspecten verandering hadden ervaren, "weinig verandering" verwijst naar één verandering in hun werk en "veel veranderingen" verwijst naar twee tot vier veranderingen in hun werk. Chi-square toetsen laten zien dat veranderingen in werkuren vaak samengaan met veranderingen in verantwoordelijkheden $(p=0.002)$ en verandering in moeilijkheidsgraad $(p=$ o.016). Daarnaast gaan veranderingen in verantwoordelijkheden vaak samen met veranderingen van moeilijkheidsgraad $(p<0.001)$. Andere veranderingen in het werk hangen niet significant met elkaar samen.

Werkkenmerken. Kwantitatieve werkdruk werd gemeten met drie items van Van Veldhoven et al. (2014), waaronder "Heeft u te veel werk te doen?" (1 = nooit, $5=$ heel vaak, Cronbach's $\alpha=0.89$ ). Emotionele belasting werd gemeten met vijf items (Van Veldhoven et al., 2014), waaronder "Komt u voor uw werk in aangrijpende situaties terecht?" ( $1=$ nooit, $5=$ heel vaak, Cronbach's $\alpha=$ 0.74). Lichamelijke belasting werd gemeten met één item (Demerouti et al., 2009), namelijk "Mijn werk eist lichamelijk veel van mij" ( 1 = geheel mee oneens, 5 = geheel mee eens). Ten slotte werd autonomie gemeten met drie 
items (Morgeson \& Humphrey, 2006), waaronder "Ik heb de mogelijkheid om zelf te bepalen hoe ik mijn werk uitvoer" ( $1=$ geheel mee oneens, $5=$ geheel mee eens, Cronbach's $\alpha=0.74$ ).

Burn-outklachten. Burn-outklachten werden gemeten met vijf op Schaufeli en Van Dierendonck (2000) gebaseerde items over uitputting (CBS/TNO, 2019), waaronder "Aan het einde van een werkdag voel ik me leeg" (1 = nooit, 7 = elke dag, Cronbach's $\alpha=0.90$ ).

Bevlogenheid. Dit concept werd gemeten met de items van de UWES-3schaal (Schaufeli et al., 2019), respectievelijk: "Op mijn werk bruis ik van de energie" (vitaliteit), "Ik ben enthousiast over mijn baan" (toewijding) en "Ik ga helemaal op in mijn werk" (absorptie) ( 1 = geheel mee oneens, $5=$ geheel mee eens, Cronbach's $\alpha=0.72$ ).

Werk- en loopbaantevredenheid. Beide variabelen werden in dit onderzoek gemeten met één item (op basis van Wanous et al., 1997), respectievelijk "Over het algemeen ben ik zeer tevreden met mijn werk" en "Over het algemeen ben ik zeer tevreden met mijn loopbaan" ( $1=$ geheel mee oneens, $5=$ geheel mee eens).

Duurzame inzetbaarheid. Duurzame inzetbaarheid is in dit onderzoek gemeten met drie items. Artsen gaven in twee items aan in hoeverre zij dachten geestelijk en lichamelijk in staat te zijn om tot de pensioenleeftijd door te werken als arts, namelijk "Ik ben [geestelijk in staat (item 1)/lichamelijk in staat (item 2)] om tot mijn 67e door te werken in mijn huidige beroep" ( $1=$ geheel mee oneens, 5 = geheel mee eens). Daarnaast gaven zij in één item aan in hoeverre zij door wilden werken tot de pensioenleeftijd in hun huidige beroep, respectievelijk "Ik wil graag tot mijn 67e doorwerken in mijn huidige beroep" ( 1 = geheel mee oneens, 5 = geheel mee eens) (vgl. Oude Hengel et al., 2012). Duurzame inzetbaarheid werd gemeten als het gemiddelde van de mate waarin artsen aangeven door te kunnen en door te willen werken $(\mathrm{r}=$ $.67, \mathrm{p}<0.001)$. Om ervoor te zorgen dat beide aspecten, kunnen en willen, even zwaar wegen, is voor de mate waarin artsen aangaven door te kunnen werken, het gemiddelde genomen van hun perceptie van de mate waarin zij geestelijk en lichamelijk in staat zijn om door te werken.

Werkvermogen. Aan de artsen werd gevraagd om hun werkvermogen retrospectief te beoordelen voor de periode vóór de COVID-19-crisis en voor de periode ten tijde van het onderzoek, op een schaal van 1 tot 10. Met 
werkvermogen wordt het vermogen van artsen om hun huidige werk uit te blijven voeren bedoeld (Ilmarinen et al., 2015). De items zijn respectievelijk "Geef aan welk rapportcijfer het meest overeenkomt met ...", "... uw werkvermogen over het algemeen (dus voor de COVID-19-crisis)" en “... uw huidige werkvermogen".

Lichamelijke en psychische gezondheid. Aan de artsen is verder gevraagd hoe zij hun lichamelijke en psychische gezondheid beoordelen vóór de COVID-19-crisis, alsmede ten tijde van het afnemen van de vragenlijst, dus tijdens de COVID-19-crisis. Bijvoorbeeld: "Op een schaal van 1 tot 10 (waarbij 1 het laagst is en 10 het hoogst), hoe beoordeelt $u$ uw huidige lichamelijke gezondheid?"

\subsection{Statistische analyse}

Er werden variantieanalyses uitgevoerd om te analyseren of werkbeleving in de periode tijdens de COVID-19-crisis significant verschilde ten opzichte van de situatie voor de COVID-19-crisis. Verder werden multivariate en univariate ANOVA's uitgevoerd om het effect van het aantal COVID-19 gerelateerde veranderingen op de werkuitkomsten en werkkenmerken van MDL-artsen te onderzoeken. Tot slot zijn mediatie-analyses uitgevoerd met behulp van PROCESS (Hayes, 2013) om de relatie tussen COVID-19 gerelateerde veranderingen in het werk en elke afzonderlijk werkkenmerk en elk afzonderlijke uitkomstvariabele te analyseren (vgl. Zhao et al., 2010), waarbij steeds gecontroleerd werd voor de effecten van leeftijd, sekse en functie (medisch specialist versus arts-assistent). Tabel 1 geeft de gemiddelden, standaarddeviaties en correlaties weer van de belangrijkste variabelen in deze studie. 


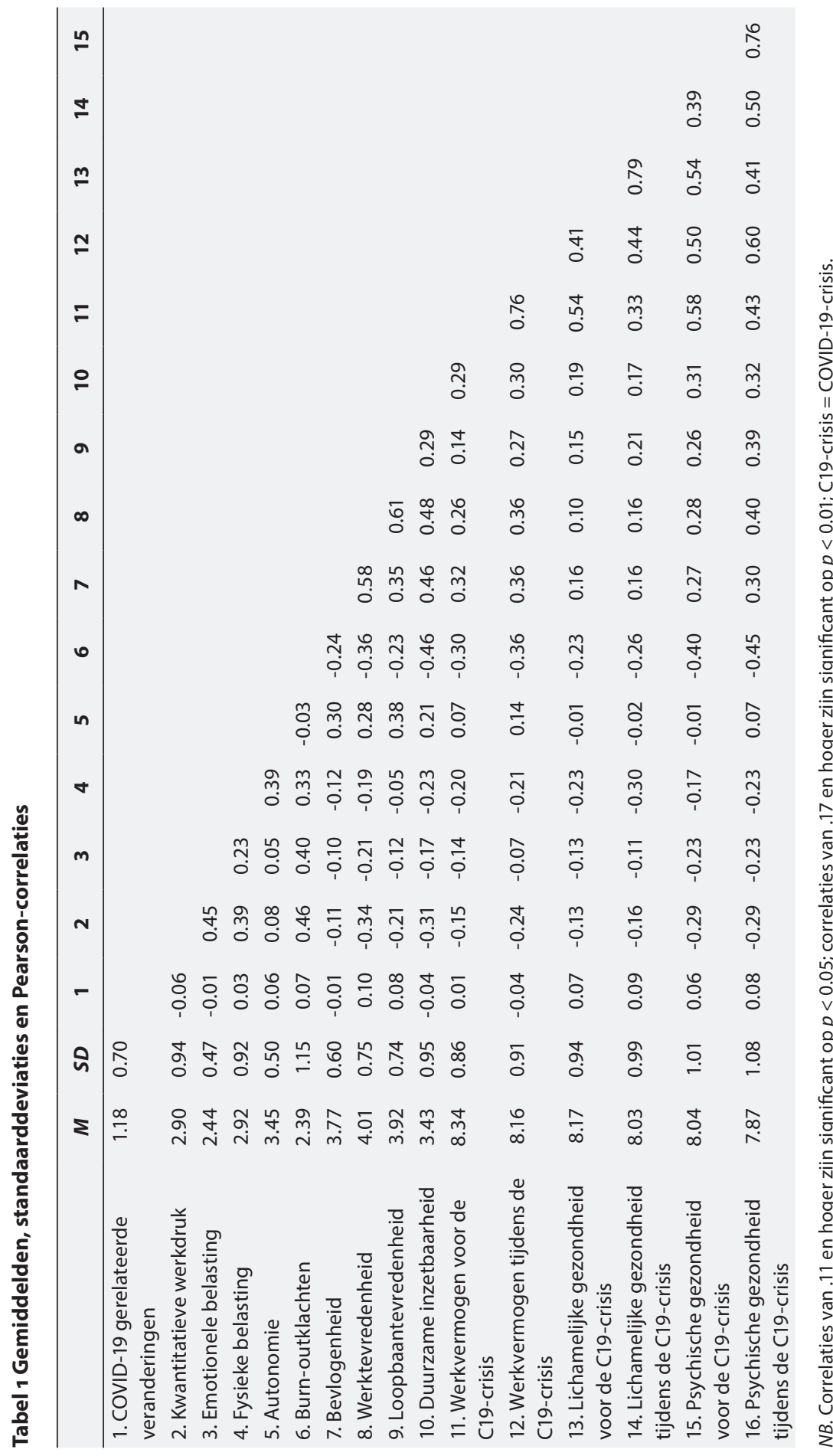




\section{$3 \quad$ Resultaten}

\subsection{Veranderingen als gevolg van de COVID-19-crisis}

Bij wijze van exploratieve onderzoeksvraag werd nagegaan hoe de deelnemende MDL-artsen hun werk vóór en tijdens de COVID-19-crisis ervoeren. De deelnemers werkten significant minder uren tijdens de COVID-19-crisis $(M=39.84 ; S D=13.60)$ dan vóór de COVID-19-crisis $(M=47.95 ; S D=11.45)$, $t(228)=11.32, p<0.001$, Cohen's $d=0.65$. Daarnaast zijn MDL-artsen positief over hun werkvermogen, lichamelijke gezondheid en psychische gezondheid zowel tijdens de COVID-19-crisis als voor de COVID-19-crisis. Wel zijn ze significant negatiever over hun werkvermogen $(t(228)=4.42, p=0.001$, Cohen's $d=0.20)$, lichamelijke gezondheid $(t(228)=3.25, p<0.001$, Cohen's $d=0.15)$ en psychische gezondheid $(t(228)=3.58, p<0.001$, Cohen's $d=0.16)$ tijdens de COVID-19-crisis (werkvermogen: $M=8.16$; $S D=0.91$; lichamelijke gezondheid: $M=8.03 ; S D=0.99$; psychische gezondheid: $M=7.87 ; S D=1.08$ ) ten opzichte van de situatie voor de COVID-19-crisis (werkvermogen: $M=$ 8.34; $S D=0.86$; lichamelijke gezondheid: $M=8.17 ; S D=0.94$; psychische gezondheid: $M=8.04 ; S D=1.01$ ).

MDL-artsen werkten gemiddeld $25 \%$ van hun tijd thuis tijdens de COVID19-crisis, ten opzichte van $7 \%$ van hun tijd voor de COVID-19-crisis. 9\% van de artsen werkte op een COVID-19-cohortafdeling en $5 \%$ werkte op de Intensive Care-afdeling tijdens het hoogtepunt van de COVID-19-crisis. Daarnaast gaf $23 \%$ van de MDL-artsen aan dat zij meer verantwoordelijkheden hadden gekregen tijdens de COVID-19-crisis, $11 \%$ gaf aan minder verantwoordelijkheid in het werk te hebben gekregen en voor $66 \%$ was de hoeveelheid verantwoordelijkheid in het werk hetzelfde gebleven. $9 \%$ van de MDL-artsen gaf aan dat ze tijdens de COVID-19-crisis taken van een hoger niveau moesten uitvoeren, $7 \%$ gaf aan dat hun taken van een lager niveau waren, en voor $85 \%$ was de moeilijkheidsgraad van hun werk niet veranderd.

\subsection{Effect van COVID-19 gerelateerde veranderingen op werkuitkomsten en werkkenmerken}

In deze studie hebben we gekeken naar de relatie tussen COVID-19 gerelateerde veranderingen in het werk en de werkuitkomsten en werkkenmerken van MDL-artsen. Hypothesen 2 en 3 veronderstelden dat naarmate er meer veranderingen hebben plaatsgevonden in het werk van MDL-artsen als gevolg van COVID-19, zij minder gunstige werkuitkomsten (Hypothese 2), lagere scores voor hulpbronnen en hogere scores voor taakeisen (Hypothese 3) zouden rapporteren. Tabel 2 presenteert de gemiddelden van de drie onderscheiden groepen op werkuitkomsten en werkkenmerken. Een 
multivariate ANOVA laat zien dat er significante verschillen zijn in deze variabelen voor artsen die geen, weinig of meerdere veranderingen in hun werk ervoeren als gevolg van COVID-19, $F(2,402)=1.70, p=0.02$, partial $\eta^{2}$ $=0.01$. Een univariate ANOVA laat zien dat artsen die een verschillende mate van COVID-19 gerelateerde veranderingen rapporteren, significant verschillen in hun ervaren burn-outklachten $(F(2,223)=3.57, p=0.03, f=0.15)$ en werkdruk $(F(2,223)=3.47, p=0.03, f=0.19)$. Een post-hoc Tukey-toets liet zien dat artsen die veel veranderingen in hun werk ervaren, significant vaker burn-outklachten rapporteren dan artsen die weinig veranderingen in hun werk ervaren $(p=0.03)$. Daarnaast gaven artsen die weinig veranderingen in hun werk ervaren aan dat zij een significant lagere kwantitatieve werkdruk ervaren dan andere artsen $(p=0.03)$. In beide gevallen geldt dus dat de groep die weinig veranderingen in hun werk als gevolg van COVID-19 ervoer (en niet de groep die geenveranderingen ervoer), de meest gunstige scores rapporteerde. Voor de andere werkkenmerken en -uitkomsten werden geen significante verschillen gevonden (Hypothesen 2 en 3 niet ondersteund). ${ }^{1}$

\subsection{Mediatie-effecten van werkkenmerken}

In dit onderzoek hebben we ook gekeken of de relaties tussen COVID-19 gerelateerde veranderingen en werkuitkomsten gemedieerd worden door werkkenmerken (kwantitatieve werkdruk, emotionele belasting, fysieke belasting en autonomie, Hypothese 4). De uitkomsten van deze analyses worden weergegeven in Tabel 3. Deze tabel laat zien dat het effect van het aantal COVID-19 gerelateerde veranderingen op werkuitkomsten $(x \rightarrow y$, Hypothese 2) varieert van -0.02 tot 0.11 (gemiddelde absolute $\beta$ is 0.07 ) en voor geen enkele werkuitkomst significant is op $p<0.05$. Deze resultaten bevestigen de hierboven gerapporteerde resultaten van de variantieanalyses.

Ook de effecten van het aantal COVID-19 gerelateerde veranderingen op de beoogde mediatoren kwantitatieve werkdruk, fysieke en emotionele belasting, en autonomie $(x \rightarrow m)$ zijn niet significant ( $\beta$ 's variëren van -0.02 tot o.09, gemiddelde absolute $\beta=0.06$, alle $p$ 's $>0.05$ ). Hypothese 3 , namelijk dat deelnemers die meer veranderingen in hun werk als gevolg van COVID-19 ervaren, lagere scores rapporteren voor hulpbronnen en hogere scores voor taakeisen, wordt hiermee nogmaals verworpen. De volstrekte afwezigheid van significante effecten van het aantal COVID-19 gerelateerde veranderingen op werkkenmerken en -uitkomsten impliceert dat er geen sprake is van enige vorm van mediatie (Hypothese 4 verworpen). 
Tabel 2 Werkuitkomsten en werkkenmerken van MDL-artsen als functie van aantal veranderingen in het werk als gevolg van de COVID-19-crisis (gemeten tijdens de crisis)

\begin{tabular}{|c|c|c|c|c|c|c|c|c|}
\hline & \multicolumn{2}{|c|}{$\begin{array}{c}\text { Geen } \\
\text { veranderingen } \\
(n=38)\end{array}$} & \multicolumn{2}{|c|}{$\begin{array}{c}\text { Weinig } \\
\text { veranderingen } \\
(n=110)\end{array}$} & \multicolumn{2}{|c|}{$\begin{array}{c}\text { Veel } \\
\text { veranderingen } \\
(n=78)\end{array}$} & \multirow[b]{2}{*}{$\begin{array}{c}F \\
(2,223)\end{array}$} & \multirow[b]{2}{*}{$\begin{array}{l}\text { Effect } \\
\text { sizef }\end{array}$} \\
\hline & $M$ & $S D$ & $M$ & $S D$ & $M$ & $S D$ & & \\
\hline $\begin{array}{l}\text { Burn- } \\
\text { outklachten }\end{array}$ & 2.52 & 1.19 & 2.18 & 0.97 & 2.61 & 1.33 & $3.57^{*}$ & 0.15 \\
\hline Bevlogenheid & 3.78 & 0.74 & 3.77 & 0.51 & 3.76 & 0.65 & 0.02 & 0.01 \\
\hline $\begin{array}{l}\text { Werktevre- } \\
\text { denheid }\end{array}$ & 3.76 & 0.88 & 4.01 & 0.65 & 4.04 & 0.80 & 2.63 & 0.13 \\
\hline $\begin{array}{l}\text { Loopbaan- } \\
\text { tevredenheid }\end{array}$ & 3.87 & 0.88 & 3.87 & 0.72 & 4.01 & 0.70 & 0.93 & 0.08 \\
\hline $\begin{array}{l}\text { Duurzame } \\
\text { inzetbaarheid }\end{array}$ & 3.39 & 1.12 & 3.51 & 0.91 & 3.33 & 0.92 & 0.83 & 0.08 \\
\hline $\begin{array}{l}\text { Werkvermo- } \\
\text { gen }\end{array}$ & 8.16 & 0.92 & 8.21 & 0.88 & 8.09 & 0.95 & 0.42 & 0.05 \\
\hline $\begin{array}{l}\text { Lichamelijke } \\
\text { gezondheid }\end{array}$ & 7.97 & 1.03 & 7.95 & 0.99 & 8.19 & 0.98 & 1.46 & 0.10 \\
\hline $\begin{array}{l}\text { Psychische } \\
\text { gezondheid }\end{array}$ & 7.61 & 1.35 & 7.94 & 0.92 & 7.91 & 1.12 & 1.43 & 0.12 \\
\hline $\begin{array}{l}\text { Kwanti- } \\
\text { tatieve } \\
\text { werkdruk }\end{array}$ & 3.21 & 0.97 & 2.77 & 0.91 & 2.95 & 0.94 & $3.47^{*}$ & 0.19 \\
\hline $\begin{array}{l}\text { Emotionele } \\
\text { belasting }\end{array}$ & 2.52 & 0.46 & 2.39 & 0.44 & 2.47 & 0.49 & 0.24 & 0.11 \\
\hline $\begin{array}{l}\text { Fysieke } \\
\text { belasting }\end{array}$ & 3.07 & 1.01 & 2.79 & 0.88 & 3.06 & 0.90 & 0.07 & 0.12 \\
\hline Autonomie & 3.51 & 0.52 & 3.41 & 0.47 & 3.55 & 0.43 & 0.10 & 0.12 \\
\hline
\end{tabular}

$N B .^{*}=$ significant op $p<0.05$; overall multivariate $F(2,402)=1.70, p=0.02$, partial $\eta^{2}=0.01$. 
Tabel 3 Gestandaardiseerde regressie-effecten voor de relaties tussen aantal COVID-19 gerelateerde veranderingen in het werk $(x)$ en werkuitkomsten zoals gemeten tijdens de crisis (y), met werkkenmerken $(\mathrm{m})$ als mediator

\begin{tabular}{|c|c|c|c|c|c|}
\hline & & \multicolumn{4}{|c|}{ Mediatoren $(m)$} \\
\hline \multicolumn{2}{|l|}{$\begin{array}{l}\text { Werkuitkomsten } \\
\text { (y) }\end{array}$} & $\begin{array}{c}\text { Kwantitatieve } \\
\text { werkdruk }\end{array}$ & $\begin{array}{l}\text { Emotionele } \\
\text { belasting }\end{array}$ & $\begin{array}{c}\text { Fysieke } \\
\text { belasting }\end{array}$ & Autonomie \\
\hline & & $\beta$ & $\beta$ & $\beta$ & $\beta$ \\
\hline \multirow[t]{4}{*}{ Burn-outklachten } & $x \rightarrow y$ & \multicolumn{4}{|c|}{0.04} \\
\hline & $x \rightarrow m$ & -0.06 & -0.02 & 0.04 & 0.09 \\
\hline & $m \rightarrow y$ & $0.46^{* *}$ & $0.38^{* *}$ & $0.32^{* *}$ & 0.02 \\
\hline & $x \rightarrow y(m)$ & 0.06 & 0.06 & 0.03 & 0.04 \\
\hline \multirow[t]{4}{*}{ Bevlogenheid } & $x \rightarrow y$ & \multicolumn{4}{|c|}{0.01} \\
\hline & $x \rightarrow m$ & -0.06 & -0.02 & 0.04 & 0.09 \\
\hline & $m \rightarrow y$ & -0.11 & -0.10 & -0.12 & $0.30^{* *}$ \\
\hline & $x \rightarrow y(m)$ & 0.01 & 0.01 & 0.02 & -0.02 \\
\hline \multirow[t]{4}{*}{ Werktevredenheid } & $x \rightarrow y$ & \multicolumn{4}{|c|}{0.11} \\
\hline & $x \rightarrow m$ & -0.06 & -0.02 & 0.04 & 0.09 \\
\hline & $m \rightarrow y$ & $-0.33^{* *}$ & $-0.23^{* *}$ & $-0.18^{* *}$ & $0.25^{* *}$ \\
\hline & $x \rightarrow y(m)$ & 0.10 & 0.11 & 0.12 & 0.09 \\
\hline \multirow{4}{*}{$\begin{array}{l}\text { Loopbaantevre- } \\
\text { denheid }\end{array}$} & $x \rightarrow y$ & \multicolumn{4}{|c|}{0.10} \\
\hline & $x \rightarrow m$ & -0.06 & -0.02 & 0.04 & 0.09 \\
\hline & $m \rightarrow y$ & $-0.20 * *$ & $-0.14^{*}$ & -0.04 & $0.36^{* *}$ \\
\hline & $x \rightarrow y(m)$ & 0.10 & 0.10 & 0.10 & 0.07 \\
\hline \multirow{4}{*}{$\begin{array}{l}\text { Duurzame } \\
\text { inzetbaarheid }\end{array}$} & $x \rightarrow y$ & \multicolumn{4}{|c|}{-0.02} \\
\hline & $x \rightarrow m$ & -0.06 & -0.02 & 0.04 & 0.09 \\
\hline & $m \rightarrow y$ & $-0.31^{* *}$ & $-0.19 * *$ & $-0.22^{* *}$ & $0.20^{* *}$ \\
\hline & $x \rightarrow y(m)$ & -0.03 & -0.02 & -0.01 & -0.04 \\
\hline \multirow[t]{4}{*}{ Werkvermogen } & $x \rightarrow y$ & \multicolumn{4}{|c|}{-0.02} \\
\hline & $x \rightarrow m$ & -0.06 & -0.02 & 0.04 & 0.09 \\
\hline & $m \rightarrow y$ & $-0.25^{* *}$ & -0.07 & $-0.21^{* *}$ & 0.10 \\
\hline & $x \rightarrow y(m)$ & -0.03 & -0.02 & -0.01 & -0.03 \\
\hline \multirow{4}{*}{$\begin{array}{l}\text { Lichamelijke } \\
\text { gezondheid }\end{array}$} & $x \rightarrow y$ & \multicolumn{4}{|c|}{0.09} \\
\hline & $x \rightarrow m$ & -0.06 & -0.02 & 0.04 & 0.09 \\
\hline & $m \rightarrow y$ & $-0.16^{*}$ & -0.12 & $-0.30^{* *}$ & -0.06 \\
\hline & $x \rightarrow y(m)$ & 0.09 & 0.09 & 0.11 & 0.10 \\
\hline \multirow{4}{*}{$\begin{array}{l}\text { Psychische } \\
\text { gezondheid }\end{array}$} & $x \rightarrow y$ & \multicolumn{4}{|c|}{0.10} \\
\hline & $x \rightarrow m$ & -0.06 & -0.02 & 0.04 & 0.09 \\
\hline & $m \rightarrow y$ & $-0.28^{* *}$ & $-0.22^{* *}$ & $-0.23^{* *}$ & 0.03 \\
\hline & $x \rightarrow y(m)$ & 0.09 & 0.10 & 0.11 & 0.10 \\
\hline
\end{tabular}

NB. $x \rightarrow y=$ effect van veranderingen in het werk als gevolg van COVID-19 op werkuitkomst $y ; x \rightarrow$ $m=$ effect van veranderingen in het werk als gevolg van COVID-19 op mediator $m ; m \rightarrow y=$ effect van mediator $m$ op werkuitkomst $y ; x \rightarrow y(m)=$ effect van veranderingen in het werk als gevolg van COVID-19 op werkuitkomst $y$, na controle voor mediator $m$; effecten na controle voor leeftijd, sekse en functie (niet hier gerapporteerd). 
Hoewel het aantal veranderingen in het werk als gevolg van COVID-19 dus niet gerelateerd is aan werkuitkomsten en -kenmerken, laat Tabel 3 zien dat de werkkenmerken op zichzelf vaak wél significant samenhangen met de werkuitkomsten $(m \rightarrow y$, Hypothesen $1 \mathrm{a}-1 \mathrm{~b})$. Die effecten variëren van -0.33 tot 0.46 (gemiddelde gestandaardiseerde $\beta$ is 0.23 ). Naarmate MDL-artsen aangeven meer autonomie te ervaren, rapporteren zij meer bevlogenheid $(\beta=0.30)$, werktevredenheid $(\beta=0.25)$, loopbaantevredenheid $(\beta=0.36)$ en duurzame inzetbaarheid $(\beta=0.20)$. Autonomie hangt niet significant samen met burn-outklachten, werkvermogen of lichamelijke en psychische gezondheid (Hypothese 1 b ondersteund, met name voor de niet-gezondheid gerelateerde werkuitkomsten).

De drie indicatoren van werkdruk/belasting hangen op sterk vergelijkbare wijze samen met de werkuitkomsten, zowel in termen van het teken van de relatie als de significantie daarvan. Algemeen gesproken geldt dat deelnemers die meer belasting/werkdruk ervaren, minder gunstige uitkomsten rapporteren. Dan gaat het bijvoorbeeld om gezondheid gerelateerde zaken als meer burn-outklachten, minder lichamelijke gezondheid, minder psychische gezondheid, een lager werkvermogen, en een mindere duurzame inzetbaarheid. Een hogere belasting gaat daarnaast ook samen met minder positieve scores op werktevredenheid en loopbaantevredenheid (Hypothese 1a ondersteund). Alleen voor bevlogenheid - een typisch motivationeel concept - werd geen enkele relatie met werkdruk/belasting gevonden.

\section{$4 \quad$ Discussie}

De COVID-19-crisis is een sluipende crisis waarvan de gevolgen in potentie nog lang kunnen naslepen (Boin, 2009) en verder kunnen reiken dan de meest voor de hand liggende groepen. Onderzoek naar pandemieën van infectieziekten laten zien dat zorgmedewerkers die direct betrokken zijn bij de zorg voor patiënten met het virus, lang last kunnen hebben van mentale klachten of verminderde inzetbaarheid (Ives et al., 2009; Ripp et al., 2020; Stuijfzand et al., 2020). Het uitgangspunt van onze studie was dat ook diegenen die niet direct betrokken zijn bij de zorg voor dergelijke patiënten, negatieve effecten kunnen ondervinden, met name omdat de veranderingen in het werk die nodig zijn om de toevloed van COVID-19-patiënten het hoofd te kunnen bieden, onbedoelde neveneffecten kunnen hebben.

In deze studie wilden we deze collateral damage in beeld brengen middels een cross-sectionele vragenlijst onder 248 Nederlandse MDL-artsen. Met het Job Demand-Resources model van Demerouti et al. (2001; Schaufeli \& 
Taris, 2013) als uitgangspunt veronderstelden we dat naarmate artsen méér veranderingen in hun werk ervoeren als gevolg van de COVID-19-crisis, zij minder gunstige scores op werkkenmerken (emotionele en fysieke belasting, werkdruk en autonomie) en werkuitkomsten (burn-outklachten, bevlogenheid, tevredenheid en inzetbaarheid) zouden rapporteren. Daarnaast werden ze bevraagd naar eventuele veranderingen in werkvermogen en lichamelijke en psychische gezondheid.

\subsection{Bevindingen}

Uit de resultaten blijkt dat artsen wel degelijk veranderingen in hun werk ervaren als gevolg van het COVID-19-virus. Van de deelnemers was 5 tot $10 \%$ ingezet (geweest) op de IC dan wel een corona-cohortafdeling; de gemiddelde werkweek van MDL-artsen bedroeg 40 uur, ten opzichte van een gemiddelde werkweek van 48 uur vóór de crisis. Daarnaast gaven MDL-artsen aan dat hun werkvermogen en lichamelijke/psychische gezondheid vóór de crisis beter waren dan tijdens de crisis. Ondanks dit verschil blijkt dat MDLartsen hun werkvermogen, en lichamelijke/psychische gezondheid voor en tijdens de COVID-19-crisis als ruim voldoende beoordelen. Een kwart van de MDL-artsen gaf aan dat zij meer verantwoordelijkheid hadden in hun werk tijdens het hoogtepunt van de COVID-19-crisis ten opzichte van de situatie vóór de crisis. Voor de grote meerderheid van de respondenten was het niveau van verantwoordelijkheid en de moeilijkheidsgraad van het werk niet veranderd.

Het verband tussen het aantal COVID-gerelateerde veranderingen dat MDL-artsen in hun werk ervoeren en werkkenmerken/werkuitkomsten, was in slechts twee van de twaalf gevallen statistisch significant. In deze twee gevallen rapporteerde de groep die weinig veranderingen in hun werk ervoer als gevolg van COVID-19, de gunstigste scores op de betreffende twee concepten (burn-outklachten en kwantitatieve werkdruk; twee concepten die onderling sterk samenhangen), niet de groep die geen veranderingen ervoer. Het is denkbaar dat de "geen veranderingen/business as usual"-groep sowieso al een hoge werkdruk ervoer en dat COVID-19 daar voor deze groep geen verandering in heeft gebracht. De met COVID-19 samenhangende veranderingen lijken met name voor de groep die weinig veranderingen rapporteerde positieve gevolgen te hebben gehad (bijvoorbeeld een afname van werkdruk doordat er minder uren konden worden gewerkt). Dit positieve effect moet overigens zeker niet worden overschat; voor veruit de meeste concepten vonden we geen enkel verband tussen de ervaren veranderingen in het werk als gevolg van COVID-19 en de werkuitkomsten en -kenmerken. Dat kan overigens ook positief worden geduid: de veranderingen in het 
werk van MDL-artsen als gevolg van de COVID-19-crisis lijken geen sterke negatieve effecten te hebben gehad op het werk en de werkuitkomsten van MDL-artsen. Tegelijkertijd laten deze uitkomsten zien dat de impact van veranderingen in het werk als gevolg van COVID-19 varieert voor verschillende MDL-artsen. Dit is in lijn met uitkomsten die laten zien dat werkbeleving in algemene zin verschillend is voor verschillende groepen artsen. Zo zijn arts-assistenten, jongere artsen en vrouwelijke artsen vaak negatiever over hun werkbeleving dan medisch specialisten, oudere artsen en mannelijke artsen (Van Leeuwen \& Taris, 2020, 2021).

De bevindingen van ons onderzoek over de relaties tussen werkkenmerken en werkuitkomsten zijn in lijn met de op het Job Demands-Resources model (Demerouti et al., 2001) gebaseerde hypothesen. De hulpbron autonomie bleek positief samen te hangen met deels motivationeel getinte werkuitkomsten als bevlogenheid, werk- en loopbaantevredenheid en duurzame inzetbaarheid. De taakeisen hingen vooral sterk samen met gezondheid-gerelateerde concepten als burn-out, lichamelijke en psychische gezondheid, werkvermogen en duurzame inzetbaarheid, al vonden we ook negatieve relaties met werk- en loopbaantevredenheid. Grosso modo werden de kernrelaties van het model ondersteund en werden daarnaast ook effecten op enkele andere uitkomstvariabelen gevonden. Dat laat zien dat het onderscheid tussen de twee in het JD-R model veronderstelde processen (taakeisen hebben vooral gezondheidseffecten, hulpbronnen vooral motivationele effecten) niet zeer scherp is. Dergelijke bevindingen zijn echter niet ongewoon (vgl. Schaufeli \& Taris, 2013) en passen bij de bevindingen van eerdere modellen die geen scherp onderscheid maken tussen dergelijke processen (bijv. onderzoek op basis van Karasek en Theorell's Demand-Control-Support model, 1990; zie voor overzichtsstudies De Lange et al., 2003; Lesener et al., 2019). Hoewel deze bevindingen misschien niet verrassend zijn, laten ze in ieder geval zien dat de door ons onderzochte groep niet atypisch is; in dat opzicht is het niet aannemelijk dat het gebrek aan sterke effecten van de ervaren impact van COVID-19 te wijten is aan bijzondere kenmerken van de onderzochte groep.

\subsection{Beperkingen}

Dit onderzoek kent enkele beperkingen. Ten eerste, de hier gerapporteerde uitkomsten zijn gebaseerd op cross-sectionele data. Hoewel cross-sectionele studies interessante inzichten kunnen opleveren over de samenhang van verschillende variabelen (Taris et al., 2021), kunnen er geen causale conclusies worden getrokken. Tot op zekere hoogte is dit bezwaar maar betrekkelijk. Het ontbreken van betekenisvolle relaties tussen het aantal COVID-19 gerelateerde veranderingen en werkkenmerken en -uitkomsten zorgt ervoor 
dat de discussie over de causaliteit van deze relaties minder relevant is. Wat betreft de verbanden tussen werkkenmerken en werkuitkomsten: eerdere longitudinale reviews hebben bevestigd dat werkkenmerken inderdaad gezien kunnen worden als antecedenten van werkuitkomsten (bijv. De Lange et al., 2003; Taris et al., 2017), al lijkt het erop dat werkuitkomsten op hun beurt ook werkkenmerken kunnen beïnvloeden (Lesener et al., 2019).

Ten tweede, enkele items in dit onderzoek hebben een retrospectief karakter. Dit komt met het nadeel dat het lastig is om situaties uit het verleden voor de geest te halen (Schwarz, 2007). Dit probleem is minder erg voor vragen die verwijzen naar langdurige periodes (Schwarz, 2007), zoals de situatie vóór de COVID-19-crisis, omdat mensen zich dit meestal nog wel kunnen herinneren. Toekomstig onderzoek zou aan de hand van longitudinale data kunnen uitzoeken of vergelijkbare uitkomsten worden gevonden als werkbeleving op verschillende momenten in de tijd gemeten wordt. Hoewel dit lastig kan zijn met data uit het verleden, bieden secundaire datasets of data die op regelmatige momenten worden verzameld, wellicht informatie over de werkbeleving vóór de COVID-19-crisis.

Een verdere beperking was dat we slechts een beperkt aantal werkkenmerken (demands en resources) hebben meegenomen in deze studie. Daaraan lagen enerzijds praktische bezwaren ten grondslag (beperkte ruimte in de vragenlijst) en anderzijds theoretische redenen (de kenmerken die wél meegenomen werden, zijn in een veelheid van beroepen relevant). De keuze voor de opgenomen werkkenmerken werd gemaakt in samenspraak met een klankbordgroep van MDL-artsen, zodat het redelijk leek om te veronderstellen dat we de allerbelangrijkste werkkenmerken in deze studie hebben meegenomen. Maar uiteraard is het achteraf denkbaar dat andere factoren minstens zo relevant zouden zijn geweest (denk bijvoorbeeld aan vaardigheidsbenutting en sociale steun).

Ten slotte, in deze studie werden de effecten onderzocht van de mate waarin MDL-artsen veranderingen in hun werk ervoeren van COVID-19. Dergelijke effecten zouden wellicht duidelijker zijn geworden als we ons niet alleen hadden gericht op deze specifieke groep medisch specialisten, maar daarbij ook andere groepen medisch specialisten zouden hebben betrokken bij wijze van vergelijkingsmateriaal. Longartsen en KNO-artsen (direct bij COVID-19 betrokken specialismen) ervaren mogelijk een veel grotere en andere impact dan - zeg - radiologen en kaakchirurgen. 


\subsection{Praktische en theoretische implicaties}

Hoewel de huidige studie vooral een toegepaste insteek had, hebben onze bevindingen wel degelijk ook theoretische implicaties. Wellicht de interessantste daarvan is dat het effect van COVID-19 gerelateerde veranderingen in het werk op de werkbeleving van de onderzochte groep mee lijkt te vallen. Alhoewel de deelnemers negatieve effecten van de crisis rapporteerden, vonden we in deze studie geen systematische verbanden tussen het aantal veranderingen in hun werk als gevolg van COVID-19 en hun werkkenmerken en werkuitkomsten. Dat suggereert dat deze veranderingen in hun werk wellicht minder ingrijpend zijn dan op voorhand wellicht gedacht zou kunnen worden, dan wel dat deze veranderingen heel goed werden begrepen door de deelnemers in ons onderzoek en daarom niet gepaard gingen met negatieve effecten. De suggesties in de pers dat tijdens de COVID-19-crisis grote delen van de Nederlandse zorg als geheel op omvallen stonden, worden in deze studie niet ondersteund.

Vanuit het oogpunt van crisisbeheersing is dit een interessante bevinding, omdat het laat zien dat de impact van een grootschalige pandemie als COVID-19 zelfs voor verschillende groepen binnen één zwaar getroffen sector als de ziekenhuizen kan verschillen: crisisbeheersing moet niet alleen op macroniveau plaatsvinden (dat van de samenleving) maar heeft ook gevolgen op microniveau (groepen en zelfs individuen in de samenleving). Dit impliceert dat het bij de aanpak van crises als deze belangrijk is om goed na te denken over de vraag welke maatregelen een bepaalde - negatieve of positieve - impact hebben voor specifieke groepen. Meer algemeen weten we bijvoorbeeld dat introverte mensen positief reageerden op de beperkende maatregelen die overheden troffen vanwege COVID-19, terwijl dit niet gold voor extraverte mensen (Wijngaards et al., 2020); de crisis van de één is niet per se ook de crisis van de ander. In die zin benadrukken onze bevindingen het belang om de impact van crises voor specifieke groepen in kaart te brengen.

Vanuit praktisch oogpunt laat onze studie zien dat er voor de hier onderzochte groep van MDL-artsen geen overtuigende redenen zijn om te vrezen dat COVID-19 sterke negatieve effecten heeft op hun werkkenmerken en werkbeleving. Er is in dat opzicht ook geen noodzaak om die werkomstandigheden en -uitkomsten in algemene zin aan te pakken. Dat laat echter onverlet dat er in individuele gevallen wél serieuze problemen aanwezig kunnen zijn. Het is daarmee aan collega's en (vooral) leidinggevenden om na te gaan of en in hoeverre individuele artsen goed in hun vel zitten, en hoe eventuele problemen aangepakt kunnen worden. Algemeen gesproken lijken 
MDL-artsen echter goed om te kunnen gaan met de impact die COVID-19 gerelateerde veranderingen hebben op hun werk.

\subsection{Conclusie}

Ons onderzoek laat zien dat veranderingen in het werk als gevolg van COVID-19 een geringe impact hebben op de werkbeleving van in Nederlandse ziekenhuizen werkzame MDL-artsen. Alhoewel de deelnemers enige negatieve effecten rapporteren met betrekking tot hun gezondheid en belasting, hebben de veranderingen in hun werk geen duidelijke negatieve effecten op hun werkbeleving. Daarmee laat deze studie zien dat veranderingen in het werk als gevolg van de COVID-19-crisis ten tijde van deze studie (nog) niet hebben geleid tot collateral damage voor de gezondheid en de werkbeleving van deze groep medici. ${ }^{2}$

\section{Praktijkbox}

Wat betekenen de resultaten voor de praktijk?

- Nederlandse ziekenhuizen hebben als gevolg van de COVID-19-pandemie de manier van werken moeten veranderen, maar dit heeft niet geleid tot duidelijke negatieve effecten op de werkbeleving van MDL-artsen.

- Het is denkbaar dat het effect van COVID-19 gerelateerde veranderingen in het werk op werkbeleving verschilt tussen beroepsgroepen (en zelfs tussen personen) binnen één organisatie. Niet iedereen zal een crisis op dezelfde manier ervaren; sommigen zullen zelfs positieve effecten ervaren.

- Het bovenstaande benadrukt het belang van persoonlijke aandacht van bijvoorbeeld leidinggevenden en collega's voor de mogelijke impact van de COVID-19-crisis op de werkbeleving van individuen, en waar nodig maatwerk te bieden.

- Werkkenmerken hangen significant samen met werkuitkomsten, zonder invloed van de COVID-19-pandemie. Artsen die meer belasting/werkdruk ervaren, rapporteren minder gunstige uitkomsten. Dit benadrukt het belang van aandacht voor de werkbeleving van (MDL-)artsen, ook in 'normale' tijden. 


\section{Noten}

1. In aanvulling op bovenstaande analyses zijn post-hoc analyses uitgevoerd om de relatie tussen de afzonderlijke veranderingen in het werk als gevolg van COVID-19 (namelijk werkuren, werklocatie, verantwoordelijkheden en moeilijkheidsgraad) op werkkenmerken en werkuitkomsten te onderzoeken. Analyse op het niveau van de afzonderlijke veranderingen levert nauwelijks andere inzichten op dan een analyse op het niveau van de veranderingen tezamen, zoals hierboven vermeld. De post-hoc analyses resulteren alleen in significante verschillen voor veranderingen in verantwoordelijkheden. Specifiek blijkt dat percepties van huidige lichamelijke gezondheid significant lager zijn voor degenen die aangaven dat hun verantwoordelijkheid hetzelfde bleef $(M=7.93 ; S D=0.98)$, t.o.v. degenen die aangaven dat hun verantwoordelijkheid toenam gedurende de COVID-19-crisis $(M=8.38$; $S D=0.93 ; F(2,226)=4.32, p=0.01)$. Daarnaast blijkt dat de percepties van emotionele belasting significant lager zijn voor degenen die aangaven dat hun verantwoordelijkheid hetzelfde bleef $(M=2.41 ; S D=0.44)$ dan voor degenen die aangaven dat ze minder verantwoordelijkheden hadden ten tijde van de COVID-19-crisis $(M=2.68 ; S D=0.58 ; F(2,240)=4.17, p=0.02)$. Verder blijkt dat werkkenmerken en werkuitkomsten niet beïnvloed worden door de mate waarin werkuren zijn veranderd, alle $p$ 's $>0.158$, de mate waarin de moeilijkheidsgraad van het werk is veranderd, alle $p$ 's $>0.128$, en de mate waarin MDL-artsen op een andere locatie moesten werken, alle $p$ 's > 0.061. Uiteindelijk bleken twee van de 48 hier onderzochte relaties significant te zijn, wat niet afwijkt van wat op basis van toeval kan worden verwacht.

2. De auteurs willen het bestuur van de Nederlandse Vereniging van MaagDarm-Leverartsen bedanken voor de kans om dit onderzoek onder hun leden uit te voeren. In het bijzonder bedanken we Johan Kuyvenhoven, Marc Verhagen en Marijn Radersma voor hun rol als leden van de klankbordgroep. Daarnaast willen we de MDL-artsen bedanken die de moeite hebben genomen om de vragenlijst in te vullen.

\section{Literatuur}

Boin, A. (2009). The new world of crises and crisis management: Implications for policymaking and research. Review of Policy Research, 26(4), 367-377. https:// doi.org/10.1111/j.1541-1338.2009.00389.x

Boin, A., Ekengren, M., \& Rhinard, M. (2020). Hiding in plain sight: Conceptualizing the creeping crisis. Risks, Hazards \& Crisis in Public Policy, 11(2), 116-138. http:// doi.org/10.1002/rhc3.12193

Brubaker, L. (2020). Women physicians and the COVID-19 pandemic. JAMA, 324(9), $835^{-8} 836$. 
Burke, R. J., \& Greenglass, E. R. (2001). Hospital restructuring, work-family conflict and psychological burnout among nursing staff. Psychology \& Health, 16(5), 583-594. http://doi.org/10.1080/08870440108405528.

CBS/TNO. (2019). Psychosociale arbeidsbelasting; beroep. Geraadpleegd op 12-04-2021 op opendata.cbs.nl/\#/CBS/nl/dataset/84436NED/table?ts=1600932598507

Crawford, E. R., LePine, J. A., \& Rich, B. L. (2010). Linking job demands and resurces to employee engagement and burnout: A theoretical extension and meta-analytic test.Journal of Applied Psychology, 95(5), 834-848. http://doi.org/10.1037/aoo19364.

De Lange, A. H., Taris, T. W., Kompier, M. A. J., Houtman, I. L. D., \& Bongers, P. M. (2003). The very best of the millennium: Longitudinal research and the Demand-Control(-Support) model.Journal of Occupational Health Psychology, 8(4), 282-305. https://doi.org/10.1037/1076-8998.8.4.282

De Vroege, L., Gribling, G., \& Van den Broek, A. (2020). "Vergeet jezelf niet, als je voor een ander zorgt": Mentale ondersteuning van zorgprofessionals tijdens de COVID-19-crisis. Tijdschrift voor Psychiatrie, 62, 424-426.

Demerouti, E., Bakker, A. B., Nachreiner, F., \& Schaufeli, W. B. (2001). The Job Demands-Resources Model of burnout. Journal of Applied Psychology, 86(3), 499-512. http://doi.org/10.1037//oo21-9010863499

Demerouti, E., Le Blanc, P. M., Bakker, A. B., \& Schaufeli, W. B. (2009). Present but sick: A three-wave study on job demands, presenteeism and burnout. Career Development International, 14(1), 50-68. http://doi.org/doi:10.1108/13620430910933574

Fila, M. (2016). The job demands, control, support model: Where are we now? TKM International Journal for Research in Management, 1(1), 15-44.

Gan, W. H., Lim, J. W., \& Koh, D. (2020). Preventing intra-hospital infection and transmission of Coronavirus disease 2019 in healthocare workers. Safety \& Health at Work, 11(2), 241-243. http://doi.org/j.shaw.2020.03.001

Hayes, A. F. (2013). Introduction to mediation, moderation and conditional process analysis: A regression-based approach. Guilford Publications.

Ilmarinen, V., Ilmarinen, J., Huuhtanen, P., Louhevaara, V., \& Näsman, O. (2015). Examining the factorial structure, measurement invariance and convergent and discriminant validity of a novel self-report measure of work ability: Work ability - personal radar. Ergonomics, 58(8), 1445-146o. http://doi.org/10.108o/o 0140139.2015.1005167

Ives, J., Greenfield, S., Parry, J. M., Draper, H., Gratus, C., Petts, J. I., Sorell, T., \& Wilson, S. (2009). Healthcare workers' attitudes to working during pandemic influenza: A qualitative study. BMC Public Health, 9(45), 1-13. http://doi. org/10.1186/1471-2458-9-56

Karasek, R., \& Theorell, T. (1990). Healthy work: Stress, productivity, and the reconstruction of working life. Basic Books. 
Lai, J., Ma, S., Wang, Y., Cai, Z., Hu, J., Wei, N., Wu, J., Du, H., Chen, T., Li, R., Tan, H., Kang, L., Yao, L., Huang, M., Wang, H., Wang, G., Liu, Z., \& Hu, S. (2020). Factors associated with mental health outcomes among health care workers exposed to coronavirus disease 2019.JAMA Network Open, 3(3), 1-12. http://doi.org/10.1001/ jamanetworkopen.2020.3976

Lesener, T., Gusy, B., \& Wolter, C. (2019). The Job Demands-Resources model: A meta-analytic review of longitudinal studies. Work \& Stress, 33(1), 76-103. http:// doi.org/10.1080/02678373.2018.1529065

Morgeson, F. P., \& Humphrey, S. E. (2006). The work design questionnaire (WDQ): Developing and validating a comprehensive measure for assessing job design and the nature of work. Journal of Applied Psychology, 91(1), 1321-1339. http://doi. org/10.1037/0021-9010.91.6.1321

Noordegraaf, M. (2015). Hybrid professionalism and beyond: (New) forms of public professionalism in changing organizational and societal contexts. Journal of Professions and Organization, 2(2), 187-206. http://doi.org/10.1093/jpo/jovoo2

Noordegraaf, M. (2020). Protective or connective professionalism? How connected professionals can (still) act as autonomous and authoritative experts.Journal of Professions and Organization, 7(2), 205-223. http://doi.org/10.1080/14719037. 2015.1066416

Oude Hengel, K. M., Blatter, B., Geuskens, G. A., Koppes, L. L. J., \& Bongers, P. M. (2012). Factors associated with the ability and willingness to continue working until the age of 65 in construction workers. International Archives of Occupational and Environmental Health, 85(7), 783-79o. http://doi.org/10.1007/soo420-011-0719-3

Probst, T. M. (2003). Exploring employee outcomes of organizational restructuring: A Solomon four-group study. Group \& Organization Management, 28(3), 416-439. http://doi.org/10.1177/1059601102250825

Ripp, J., Peccoralo, L., \& Charney, D. (2020). Attending to the emotional wellbeing of the health care workforce in a New York city health system during the Covid-19 pandemic. Academic Medicine, 64, 1-4. http://doi.org/10.1097/ ACM.0000000000003414

Rosenthal, U., Boin, A., \& Comfort, L. C. (Eds.). (2001). Managing crises: Threats, dilemmas, opportunities. Charles C. Thomas.

Ruhle, S. A., Breitsohl, H., Aboagye, E., Baba, V., Biron, C., Correia Leal, C., Dietz, C., Ferreira, A. I., Gerich, J., Johns, G., Karanika-Murray, M., Lohaus, D., Lokke, A., Lopes, S. L., Martinez, L. F., Miraglia, M., Poethke, U., Sarwat, N., Schade, H., Steidelmuller, C., Vinberg, S., Whysall, Z., Yang, T., \& Muschalla, B. (2020). "To work, or not to work, that is the question": Recent trends and avenues for research on presenteeism. European Journal of Work and Organizational Psychology, 29(3), 344-363. http://doi.org/10.1080/1359432X.2019.1704734 
Schaufeli, W. B., Shimazu, A., Hakanen, J., Salanova, M., \& De Witte, H. (2019). An ultra-short measure for work engagement: The UWES-3 validation across five countries. European Journal of Psychological Assessment, 35(4), 577-591. http:// doi.org/10.1027/1015-5759/aooo430

Schaufeli, W. B., \& Taris, T. W. (2013). Het Job Demands-Resources model: Overzicht en kritische beschouwing. Gedrag \& Organisatie, 26(2), 182-204.

Schaufeli, W. B., \& Taris, T. W. (2014). A critical review of the Job Demands-Resources Model: Implications for improving work and health. In G. Bauer \& O. Hämmig (Eds.), Bridging occupational, organizational and public health (pp. 43-68). Springer.

Schaufeli, W. B., \& Van Dierendonck, D. (2000). Utrechtse Burnout Schaal. Swets Test Publishers.

Schwarz, N. (2007). Retrospective and concurrent self-reports: The rationale for real-time data capture. In A. Stone, S. S. Shiffman, A. Atienza et al. (Eds.). The science of real-time data capture: Self-reports in health research (pp.11-26). Oxford University Press.

Shanafelt, T. D., Hasan, O., Dyrbye, L. N., Sinsky, C., Satele, D., Sloan, J., \& West, C. P. (2015). Changes in burnout and satisfaction with work-life balance in physicians and the general US working population between 2011 and 2014. Mayo Clinic Proceedings, 9o(12), 1600-1613. http://doi.org/10.1016/j.mayocp.2015.08.023 Spoorthy, M. S., Pratapa, S. K., \& Mahant, S. (2020). Mental health problems faced by healthcare workers due to the COVID-19 pandemic - A review. Asian Journal of Psychiatry, 51, 102119. http://doi.org/10.1016/j.ajp.2020.102119

Stalpers, D., Veenstra, M., Martini, D., Lalleman, P., \& Schoonhoven, L. (2021). Maken vele handen licht werk? Geleerde lessen uit de eerste COVID-19-golf over verpleegkundige teamsamenstellingen op de Intensive Care. Gedrag \& Organisatie, 34(3). https://doi.org/10.5117/G\&O2021.3.004.STAL

Starremans, S. (2020). Apart verplegen. Nursing, 26, 18-23.

Stuijfzand, S., Deforges, C., Sandoz, V., Sajin, C. T., Jaques, C., Elmers, J., \& Horsch, A. (2020). Psychological impact of an epidemic/pandemic on the mental health of healthcare professionals: A rapid review. BMC Public Health, 20(1), 1-18. http:// doi.org/10.1186/s12889-020-09322-Z

Taris, T. W. (2002). Verliezers van de zaken-olympiade? Reorganisaties en het welzijn van werknemers. Psycholoog, 37(12), 644-649.

Taris, T. W. (in druk, 2021). Harder, beter, sneller: Biografie van het moderne werken. Walburg Pers.

Taris, T. W., Kessler, S. R., \& Kelloway, E. K. (2021). Strategies addressing the limitations of cross-sectional designs in occupational health psychology: What they are good for (and what not). Work \& Stress, 35(1), 1-5. https://doi.org/10.108o/02 678373.2021 .1888561 
Taris, T. W., Leisink, P. L. M., \& Schaufeli, W. B. (2017). Applying occupational health theories to educator stress: Contribution of the Job-Demands Resources model. In T. McIntyre, S. McIntyre, \& D. Francis (Eds.), Educator stress: An occupational health perspective (pp. 237-259). Springer.

Van Leeuwen, E. H., \& Taris, T. W. (2020). Werkbeleving van Maag-, Darm- en Leverartsen in het algemeen en tijdens Covid-19 [rapport in opdracht van de Nederlandse Vereniging Maag-, Darm- en Leverartsen NVMDL]. Universiteit Utrecht.

Van Leeuwen, E. H., \& Taris, T. W. (2021). Werkbeleving van MDL-artsen tijdens de Covid-19 pandemie. Magma, 27(1), 12-13.

Van Veldhoven, M., Prins, J., Van der Laken, P., \& Dijkstra, L. (2014). VBBA 2.o: Update van de standaard voor vragenlijstonderzoek naar werk, welbevinden en prestaties. Gildeprint.

Wallinga, J., Backer, J. A., Klinkenberg, D., Van Hoek, A. J., Hahné, S. J. M., Van der Hoek, W., \& Van den Hof, S. (2020). De Covid-19-epidemie: Indammen en afvlakken. Nederlands Tijdschrift voor de Geneeskunde, 164(D4961), 1-4.

Wanous, J. P., Reichers, A. E., \& Hudy, M. J. (1997). Overall job satisfaction: How good are single-item measures? Journal of Applied Psychology, 82(2), 247-252. http://doi.org/10.1037/0021-9010.82.2.247.

Wijngaards, I., Sisouw de Zilwa, S. C. M., \& Burger, M. J. (2020). Extraversion moderates the relationship between the stringency of Covid-19 protective measures and depressive symptoms. Frontiers in Psychology, 11, 568907. http:// doi.org/10.3389/fpsyg.2020.568907

Zhao, X., Chen, Q., \& Lynch, J. G. (2010). Reconsidering Baron and Kenny: Myths and truths about mediation analysis. Journal of Consumer Research, 37, 197-206. http://doi.org/10.1086/651257

\section{Correspondentieadres}

E. H. van Leeuwen, UMC Utrecht, Kwaliteit van Zorgen Patiëntveiligheid, Heidelberglaan 100, 3584 CS Utrecht. e.h.vanleeuwen@uu.nl 